\title{
US loses allure in foreign students' eyes
}

Geoff Brumfiel, Washington

The number of foreign students enrolling in US universities stagnated last year and may now be declining for the first time in decades, according to a series of studies released this week.

The annual report of the Institute of International Education (IIE), a New York-based organization that monitors student exchange, shows that the growth in total foreign-student enrolment at US universities grew by just $0.6 \%$ in the $2002-03$ academic year - the lowest level of growth since 1995. And in a follow-on survey of international student offices in 276 universities, most reported some decline in international enrolment this autumn, suggesting that the total number of students may actually fall in the 2003-04 academic year for the first time since 1971.

Such a drop is likely to hit US universities where it hurts: international students spend some US $\$ 12$ billion annually on tuition and living expenses, according to the IIE, and foreign graduate students fill many research and teaching jobs on campuses, particularly in science and engineering.

The 2002-03 academic year saw sharp

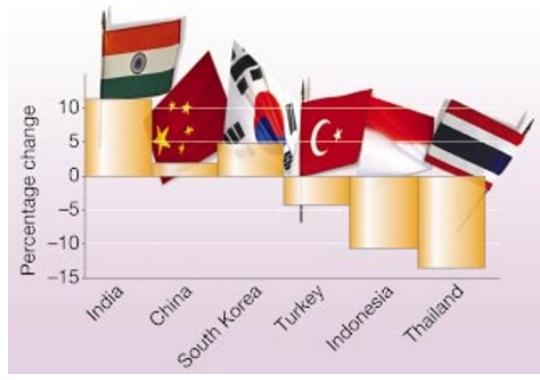

Learning curve: the changing numbers of foreign students coming to the US between 2002 and 2003.

increases in the number of students coming from India and South Korea, the IIE survey found, but the number arriving from Europe, Southeast Asia and the Middle East declined.

University administrators and academic groups attribute the slowing enrolment rates largely to the strict visa-issuance policies enacted in the wake of the terrorist attacks of 11 September 2001 (see Nature 422, $457-258 ; 2003)$. "The US government is doing more than anyone to deter foreign students," says Gail Szenes, director of the Office for International Students and Scholars at
New York University, whose campus lies just blocks from the World Trade Center, destroyed in the 2001 terror attacks. Consular interviews for students whose subject areas appear on a state department watch list are especially problematic for those studying in the sciences, Szenes says.

Visa woes are also afflicting scholars coming to teach and to do research in the United States, according to preliminary results of a separate survey by three major university associations. About three-quarters of more than 200 US universities surveyed by the associations said that they had problems getting scholars into the country, according to Victor Johnson, public-policy director at the Washington DC-based Association of International Educators, one of the groups that conducted the survey.

New visa guidelines have created a perception that it is more difficult for foreign students and scholars to come the United States, but until now, the evidence for this was largely anecdotal, according to Johnson. "These are the first data that confirm our fears," he says. http://opendoors.iienetwork.org www.nafsa.org

\section{Roaming polar bears reveal Arctic role of pollutants}

\section{Marika Willerroider, Munich}

Female polar bears have provided researchers with an insight into the long-term health impact of pollutants.

In a study published on 1 November, a Norwegian team reveals that bears that roam long distances in their search for food tend to accumulate relatively high levels of industrial pollutants such as polychlorinated biphenyls

(PCBs) in their bodies. This could be linked to the exceptional levels of hermaphroditism seen in some bear populations, although this connection has yet to be confirmed.

PCBs, which were widely used in electrical equipment until they were banned in most countries on health grounds, are extremely resistant to biodegradation. They accumulate in the food chain, even in remote locations, and then accrue at the chain's end - in polar bears, for example, which cannot easily metabolize or excrete the compounds.

The researchers tagged 54 female bears from the Svalbard archipelago and the nearby Barents Sea in the far north of Europe with satellite transmitters, and monitored their movements for several years. They found that some bears in off-

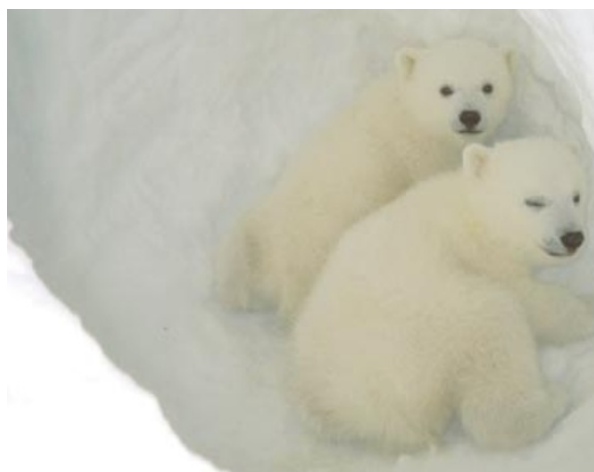

At the end of a food chain, polar bears accumulate toxic chemicals.

coast habitats roam huge territories each year - up to 270,000 square kilometres and accumulate significantly higher levels of PCBs in their fat, blood and milk than bears in smaller coastal or near-coastal habitats (G. H. Olsen et al. Environ. Sci. Technol. 37, 4919-4924; 2003).

"Long-distance migration costs immense energy," says Øystein Wiig, a mammalogist at the University of Oslo's Zoological Museum and a co-author on the study. "The bears need to consume much more prey, and thus build up more PCBs."

Particularly high pollutant concentrations were found in bears migrating to the Kara
Sea, north of Russia. This indicates that there is massive pollution of Siberian rivers from contaminated industrial areas upstream, says Wiig.

PCBs are part of a group of pollutants known as endocrine disruptors, which may interfere with hormone function in humans and animals at relatively low doses. Earlier research suggests that the PCBs could be the cause of sexual anomalies found in polar bears hermaphroditism has been seen in about $2 \%$ of the roughly $\mathbf{5 , 0 0 0}$-strong bear population in Svalbard (Ø. Wiig et al. J. Wildlife Dis. 34, 792-796; 1998).

But the link is tentative. "I'd rather not jump to conclusions. Hermaphrodites have also been found among brown bears that are free of PCBs," says Aaron Fisk, a toxicologist at the University of Georgia in Athens, who investigates pollution in arctic wildlife.

The release of PCBs into the arctic environment is slowly decreasing, says Samantha Smith, who directs the arctic programme of the WWF, an environmental group. But she warns that a second wave of pollutants, now stored in arctic ice reservoirs, may be released if glaciers melt. 